\title{
Efficacy of Nitya Virechana with Trivrit Churna in the Management of Stage 1 Essential Hypertension - A Pilot Study
}

\author{
Research Article
}

\section{Manju Mohan1*, Sawarkar Punam²}

1. PG Scholar, 2. Associate Professor, Department of Panchakarma, Mahatma Gandhi Ayurved College Hospital \& Research Centre, Wardha, Maharashtra, India

\begin{abstract}
Background: Hypertension (HTN) is a lifestyle disorder occurs due to faulty life style and stressful psychological conditions with a low rate of remission and recovery. In Ayurveda, Hypertension can be correlated with Vata Pradhana Tridoshaja Vyadhi. In Vatapradhana Vyadhi, Mridu Sanshodhana is the line of treatment and Nitya Virechana is a type of Mridu Sanshodhana. So in this study, Trivrit Churna was selected for Nitya Virechana in the management of Stage 1 Essential Hypertension. Aim: This clinical study was carried out to study the effect of Nitya Virechana with Trivrit Churna on Systolic and Diastolic blood pressure. Settings and Design: This was an openlabeled single arm interventional clinical study. Materials and Methods: Nine newly diagnosed cases of Stage 1 Essential Hypertension were registered from the outpatient and inpatient of Department of Panchakarma, Mahatma Gandhi Ayurved College Hospital \& Research Centre, Wardha, Maharashtra, India, and Nitya Virechana with Trivrit Churna was administered for consecutive 15 days. Statistical Analysis: The data were statistically analyzed using Chi-square and paired $t$ test. Results: Significant $(\mathrm{p}<0.05)$ result was found in all the assessment of subjective as well as objective parameters, namely Shiroruk (headache), Klama (fatigue), Bhrama (giddiness), Anidra (insomina), Systolic and Diastolic blood pressure. Conclusion: Nitya Virechana with Trivrit Churna is highly effective to reduce Systolic and Diastolic blood pressure with significant reduction in symptoms of Stage 1 Essential Hypertension.
\end{abstract}

Key Words: Essential Hypertension, Vata Pradhana Tridoshaja Vyadhi, Nitya Virechana, Trivrit Churna.

\section{Introduction}

Hypertension (HTN) is a lifestyle disorder occurs due to faulty lifestyle and stressful psychological conditions with a low estimate of remission and recovery. The 2017 American College of Cardiology and American Heart Association (ACC/AHA) blood pressure guidelines recommended some striking changes in the diagnosis and management of hypertension (1). Diagnostic criteria of HTN are systolic blood pressure above $130 \mathrm{~mm} \mathrm{Hg}$ and diastolic above $80 \mathrm{~mm} \mathrm{Hg}$ (1). Hypertension is called as a silent killer because majority patients $(85 \%)$ are asymptomatic (2) and cause adverse effect to brain, kidney, heart and peripheral arteries over a period (3). Hypertension is precisely responsible for $57 \%$ of all stroke deaths and $24 \%$ of all coronary heart disease (CHD) deaths in India (4). About $26.4 \%$ of the world adult population in 2000 had hypertension and $29.2 \%$ were predicted to have this disorder by 2025 (5). In $95 \%$ cases of the hypertension, the primary etiological

\section{* Corresponding Author:}

\section{Manju Mohan}

PG Scholar, Department of Panchakarma,

Mahatma Gandhi Ayurved College Hospital \& Research Centre, Wardha, Maharashtra, India.

Email Id- manjumohan13@gmail.com factors are still unknown (6) but are presumed to be due to genetic and environmental factors (7). Although antihypertensive therapy certainly reduces the risk of cardiovascular and renal disease, but lifelong usage of antihypertensive drugs is associated with detrimental effects (8). Hence to attain and maintain good health, hypertensive patients are looking towards Ayurveda.

In Ayurveda, there is no direct reference regarding this disease which completely resembles with hypertension. Many scholars had worked on hypertension and had given various nomenclature which can be correlated with hypertension such as Raktagatvata, Avruta Vata, Siragatvata, Dhamani Pratichaya, Vyana Prakopa, Raktamada etc (9) but none of these terms were universally accepted.

In Ayurveda, the regulation of blood pressure is governed by the Tridoshas viz Vata (Prana and Vyana), Pitta (Sadhaka) and Kapha (Avalambaka), Dushya like Rasa, Rakta and Meda, with the proper functioning of Mana (mind) and Oja which are situated in heart and helps in circulation of blood. On the basis of strong resemblances between etiological factors (10), symptoms (11), involvement of Doshas and Dushya in the etiopathology and complication (12), it is believed Vata Dosha to be the main culprit. Hence, Essential Hypertension can be correlated with Vata Pradhana Tridoshaja Vyadhi. 
Acharya Charaka has mentioned that if there is Bahudosha Avastha, then morbid toxins should be eliminated by the purificatory process (13). Virechana is mainly indicated in Pitta and Shonita predominant Vyadhi (14). As Pitta Dosha is having Asharaya-ashrayi Sambandha (mutual interdependence) with Rakta Dhatu, so Virechana is significantly beneficial in Rakta Dushtijanya Vyadhi (15). In Vatapradhana Vyadhi, Mridu Sanshodhana is the choice of treatment (16). Nitya Virechana is a type of Mridu Sanshodhana. There are many Virechana drugs described in Samhita. Among them, Trivrit is considered as Sukhavirechaka (17). So in this study, Trivrit Churna was selected for Nitya Virechana in the management of Stage 1 Essential Hypertension.

\section{Aims and Objectives}

To study the effect of Nitya Virechana with Trivrit Churna on Systolic and Diastolic blood pressure in Stage 1 Essential Hypertension.

\section{Materials and Methods}

A total 9 patients were registered for the study from the outpatient and inpatient of Department of Panchakarma, Mahatma Gandhi Ayurved College Hospital \& Research Centre, Wardha, Maharashtra, India, who were newly diagnosed with Stage 1 Essential Hypertension. Informed consent was obtained from the patients before starting the intervention.

\section{Inclusion Criteria}

Newly diagnosed patients of Stage 1 Essential Hypertension i.e. SBP (130-139 mm Hg) or DBP (80-89 $\mathrm{mm} \mathrm{Hg}$ ) of either sex between the age group of 30-60 years were included for the study.

\section{Exclusion Criteria}

- Patients having Stage 2 Hypertension i.e. SBP $(\geq 140$ $\mathrm{mm} \mathrm{Hg}$ ) or DBP ( $\geq 90 \mathrm{~mm} \mathrm{Hg})$.

- Hypertension associated with cardio-vascular diseases, cerebro-vascular diseases, renal function impairment, hypothyroidism, diabetes mellitus (Type1/ Type 2/ GDM), Pregnant and lactating women.

- Patients having Bleeding Hemorrhoids, Chronic Fissure-in-ano, Irritable Bowel Syndrome (IBS).

\section{Diagnostic Criteria}

The diagnostic criteria of hypertension were taken from American College of Cardiology and American Heart Association (ACC/AHA) blood pressure guidelines 2017 (1) which is shown in table 1.
Table 1: Diagnostic Criteria of Hypertension (ACC/

\section{AHA blood pressure guidelines)}

\begin{tabular}{|c|c|c|c|}
\hline $\begin{array}{l}\text { Blood } \\
\text { Pressure } \\
\text { Category }\end{array}$ & $\begin{array}{l}\text { Systolic } \\
\text { Blood } \\
\text { Pressure }\end{array}$ & & $\begin{array}{l}\text { Diastolic } \\
\text { Blood } \\
\text { Pressure }\end{array}$ \\
\hline Normal & $<120 \mathrm{~mm} \mathrm{Hg}$ & And & $<80 \mathrm{~mm} \mathrm{Hg}$ \\
\hline $\mathrm{El}$ & $\begin{array}{c}120-129 \mathrm{~mm} \\
\mathrm{Hg}\end{array}$ & And & $\mathrm{Hg}$ \\
\hline $\begin{array}{c}\text { Stage } 1 \\
\text { Hypertension }\end{array}$ & $\begin{array}{c}130-139 \mathrm{~mm} \\
\mathrm{Hg}\end{array}$ & Or & $80-89$ \\
\hline $\begin{array}{c}\text { Stage } 2 \\
\text { Hypertensior }\end{array}$ & $\geq 140 \mathrm{~mm} \mathrm{Hg}$ & Or & $\mathrm{mm} \mathrm{Hg}$ \\
\hline
\end{tabular}

\section{Investigations for screening}

All patients were screened through history and routine investigations. Hemoglobin percentage, Fasting Blood Sugar, Total Cholesterol, Triglyceride, Serum Sodium, Serum Potassium, Serum Creatinine and Electro Cardio Graph. These investigations were carried out before starting the intervention to exclude any other pathology related to exclusion criteria.

\section{Treatment}

Nitya Virechana with 10 gms of Trivrit Churna was given with lukewarm water at empty stomach around 6 a.m. for consecutive 15 days.

\section{Study Duration}

Initially treatment lasted for 15 days and follow up period after 15 days. The total study duration is 30 days.

\section{Method of administration}

The patients were briefed to do their routine work. The interventional medicine is advised to take after proper digestion of previously ingested food. The dose of Trivrit Churna administered is 10 grams with lukewarm water at 6 am IST. Instructed them to note down the proper evacuation of mala or any complaints regarding abdominal discomfort for 15 days of the study.

\section{Diet and Restrictions}

Patients were advised to take normal diet free from excessive salty, oily, sour items etc. and were also advised not to indulge in Ashtamahadoshakara Varjya Vishayas like Uchhabhashya (loud speech), Rathakshobha (travelling), Atichakramana (excessive walking), Atiasana (sedentary habit), Ajirna (intake of food during indigestion), Ahitabhojana (faulty dietary habits), Diwaswapna (daysleep) and Maithuna (sexual intercourse). 


\section{Assessment Criteria}

Subjective Criteria: Shiroruk, Klama, Bhrama and Anidra were considered as subjective parameters having grades 0 to 4 are shown in table 2.

Table 2: Assessment criteria for subjective parameters

\begin{tabular}{|c|c|c|c|c|c|c|}
\hline S.No & $\begin{array}{c}\text { Subjective } \\
\text { Criteria }\end{array}$ & Grade 0 & Grade 1 & Grade 2 & Grade 3 & Grade 4 \\
\hline 1 & $\begin{array}{c}\text { Shiroruk } \\
\text { (Headache) }\end{array}$ & Nil & $\begin{array}{l}\text { Rarely headache } \\
\text { relieves without } \\
\text { medication }\end{array}$ & $\begin{array}{l}\text { Headache } \\
\text { relieves by rest; } \\
\text { doesn't disturb } \\
\text { daily activities }\end{array}$ & $\begin{array}{l}\text { Severe headache } \\
\text { disturbs daily } \\
\text { activities requires } \\
\text { medication }\end{array}$ & $\begin{array}{l}\text { Continuous/ severe } \\
\text { headache disturbs } \\
\text { sleep and daily } \\
\text { activities and also not } \\
\text { managed by the } \\
\text { medication }\end{array}$ \\
\hline 2 & $\begin{array}{c}\text { Klama } \\
\text { (Fatigue) }\end{array}$ & Nil & $\begin{array}{l}\text { Rarely feeling of } \\
\text { tiredness without } \\
\text { any exertion }\end{array}$ & $\begin{array}{l}\text { Rarely feeling of } \\
\text { tiredness without } \\
\text { any exertion with } \\
\text { inability in } \\
\text { concentration }\end{array}$ & $\begin{array}{c}\text { Frequently feeling } \\
\text { of tiredness } \\
\text { without any } \\
\text { exertion with } \\
\text { inability in } \\
\text { concentration }\end{array}$ & $\begin{array}{l}\text { Continuous feeling of } \\
\text { tiredness without any } \\
\text { exertion with } \\
\text { inability in } \\
\text { concentration }\end{array}$ \\
\hline 3 & $\begin{array}{c}\text { Bhrama } \\
\text { (Giddiness) }\end{array}$ & Nil & $\begin{array}{l}\text { Rarely Bhrama } \\
\text { for some } \\
\text { movement } \\
\text { during change of } \\
\text { posture }\end{array}$ & $\begin{array}{l}\text { Often for some } \\
\text { movement during } \\
\text { change of posture }\end{array}$ & $\begin{array}{l}\text { Often for each } \\
\text { movement even in } \\
\text { lying condition } \\
\text { also }\end{array}$ & $\begin{array}{l}\text { Patient unable to } \\
\text { hold himself without } \\
\text { any support }\end{array}$ \\
\hline 4 & $\begin{array}{l}\text { Anidra } \\
\text { (Disturbed } \\
\text { sleep/ } \\
\text { Insomnia) }\end{array}$ & $\begin{array}{l}\text { Sound } \\
\text { sleep }\end{array}$ & $\begin{array}{l}\text { Disturbed sleep, } \\
\text { wakes-up 1-2 } \\
\text { times a night } \\
\text { (Khandita } \\
\text { Nidra) }\end{array}$ & $\begin{array}{c}\text { Difficult onset } \\
\text { sleep remains } \\
\text { disturbed in night } \\
(\text { Alpa Nidra })\end{array}$ & $\begin{array}{l}\text { Very less sleep, in } \\
\text { small intervals and } \\
\text { makes patient } \\
\text { irritable } \\
\text { (Atialpa Nidra) }\end{array}$ & $\begin{array}{l}\text { Unable to sleep } \\
\text { without medicine } \\
\text { (Anidra) }\end{array}$ \\
\hline
\end{tabular}

Objective Criteria

1. Systolic blood pressure

2. Diastolic blood pressure

\section{Assessment of Effect of Therapy}

Assessment was carried out three times, one before the treatment, second after the treatment and third after the end of follow-up period. The data were statistically analyzed using Chi-square and paired $t$ test. If $\mathrm{p}<0.05$ is considered as statistically significant result. Total effect of therapy was assessed on the basis of percentage of relief in subjective parameters.

1.Controlled

2.Marked relief

3.Moderate relief

4.Mild relief

5.No relief

\author{
$100 \%$ relief in complaints \\ $\geq 75 \%$ relief in complaints \\ $\geq 50-74 \%$ relief in complaints \\ $\geq 25-49 \%$ relief in complaints \\ $<25 \%$ relief in complaints
}

\section{Observations}

The maximum number of patients were males $(66.6 \%)$, were belonged to $50-60$ age groups $(55.5 \%)$, were Hindus (77.7\%), middle class category socioeconomic status (55.5\%). Distribution according to occupational status, it was observed that majority patients were belonging to service class (44.4\%). Mean Systolic and Diastolic blood pressure was $139.53 \mathrm{~mm} \mathrm{Hg}$ and $88.33 \mathrm{~mm} \mathrm{Hg}$ respectively. Majority of patients had family history (77.7\%). The maximum number of patients had mixed diet (55.5\%) and Lavana Rasatmaka Ahara (66.6\%). Majority patients had Vatapittaja Prakriti (44.4\%), Krura Koshta (66.6\%), Vishamagni (77.7\%), Asamyak Malapravrutti (88.8\%) and Saam Jivha (77.7\%). It was observed that majority of hypertensive patients were addicted to alcohol consumption (44.4\%) and had stress-full lifestyle (66.6\%). As per subjective parameters, it was observed that Shiroruk was observed in 1, 5 and 3 patients having Grade 2, 3 and 4 respectively. After follow up period, out of these 9 patients, 1 patient got relieved of the symptoms and remaining 5, 2 and 1 patient got significant reduction in the intensity of symptom with Grade 1, 2 and 3 respectively. Klama was observed in 1,3 and 5 patients with Grade 2, 3 and 4. After follow up period, significant reduction was observed in the severity of symptom in 1, 4 and 4 patients having Grade 0,1 and 2 . Bhrama was observed in 2, 2, 3 and 2 patients having Grade 1,2,3 and 4 respectively. Out of these 9 patients, 3 
Manju Mohan et.al., Efficacy of Nitya Virechana with Trivrit Churna in the Management of Stage 1 Essential Hypertension

patients got relieved of the symptoms and remaining 4 and 2 patients got significant reduction in the intensity of symptom with Grade 1 and 2 respectively after follow-up period. On context of Anidra, before intervention, there were 3, 2 and 4 patients were having Grade 2, 3 and 4 which got significant reduction in the intensity of symptom with 2, 5 and 2 patients having Grade 0,1 and 2 respectively after follow-up period [Table 3]. The mean values of SBP before treatment was $139.53 \pm 2.83$ which got significantly reduced to $131.14 \pm 3.05$ after intervention and after follow-up period, it again significantly reduced to $129.58 \pm 2.96$. The mean values of DBP before treatment was 88.33 \pm 2.69 which significantly reduced to $80.17 \pm 2.75$ after intervention and after follow-up period, it again reduced to $79.83 \pm 2.55$ [Table 4]. Nitya Virechana is not a proper Shodhana procedure, so the assessment of Vega is not applicable and also it was difficult to count the Vega of each patient for 15 days, but on average it was observed that Krura Koshta patients had 1-2 Vegas, whereas 2-3 Vegas was observed in Mrudu Koshta patients.

Table 3: Assessment of effect of therapy on Subjective parameters

\begin{tabular}{|c|c|c|c|c|c|c|c|}
\hline S.No. & $\begin{array}{l}\text { Assessment } \\
\text { Parameter }\end{array}$ & Grade & Before T/t & After T/t & $\begin{array}{c}\text { After } \\
\text { Follow-up }\end{array}$ & $\begin{array}{l}\chi 2 \text {-value } \\
\text { After FU }\end{array}$ & P value \\
\hline \multirow{5}{*}{1} & \multirow{5}{*}{ Shiroruk } & Grade 0 & $0(0 \%)$ & $0(0 \%)$ & $1(11.1 \%)$ & 16.76 & $<0.05, \mathrm{~S}$ \\
\hline & & Grade 1 & $0(0 \%)$ & $3(33.4 \%)$ & $5(55.6 \%)$ & & \\
\hline & & Grade 2 & $1(11.1 \%)$ & $4(44.4 \%)$ & $2(22.2 \%)$ & & \\
\hline & & Grade 3 & $5(55.5 \%)$ & $2(22.2 \%)$ & $1(11.1 \%)$ & & \\
\hline & & Grade 4 & $3(33.4 \%)$ & $0(0 \%)$ & $0(0 \%)$ & & \\
\hline \multirow{5}{*}{2} & \multirow{5}{*}{ Klama } & Grade 0 & $0(0 \%)$ & $0(0 \%)$ & $1(11.2 \%)$ & 11.89 & $<0.05, \mathrm{~S}$ \\
\hline & & Grade 1 & $0(0 \%)$ & $2(22.2 \%)$ & $4(44.4 \%)$ & & \\
\hline & & Grade 2 & $1(11.1 \%)$ & $3(33.4 \%)$ & $4(44.4 \%)$ & & \\
\hline & & Grade 3 & $3(33.4 \%)$ & $4(44.4 \%)$ & $0(0 \%)$ & & \\
\hline & & Grade 4 & $5(55.5 \%)$ & $0(0 \%)$ & $0(0 \%)$ & & \\
\hline \multirow{5}{*}{3} & \multirow{5}{*}{ Bhrama } & Grade 0 & $0(0 \%)$ & $2(22.2 \%)$ & $3(33.4 \%)$ & 10.68 & $<0.05, \mathrm{~S}$ \\
\hline & & Grade 1 & $2(22.2 \%)$ & $3(33.4 \%)$ & $4(44.4 \%)$ & & \\
\hline & & Grade 2 & $2(22.2 \%)$ & $2(22.2 \%)$ & $2(22.2 \%)$ & & \\
\hline & & Grade 3 & $3(33.4 \%)$ & $2(22.2 \%)$ & $0(0 \%)$ & & \\
\hline & & Grade 4 & $2(22.2 \%)$ & $0(0 \%)$ & $0(0 \%)$ & & \\
\hline \multirow{5}{*}{4} & \multirow{5}{*}{ Anidra } & Grade 0 & $0(0 \%)$ & $0(0 \%)$ & $2(22.2 \%)$ & 15.18 & $<0.05, \mathrm{~S}$ \\
\hline & & Grade 1 & $0(0 \%)$ & $3(33.3 \%)$ & $5(55.6 \%)$ & & \\
\hline & & Grade 2 & $3(33.4 \%)$ & $3(33.3 \%)$ & $2(22.2 \%)$ & & \\
\hline & & Grade 3 & $2(22.2 \%)$ & $3(33.3 \%)$ & $0(0 \%)$ & & \\
\hline & & Grade 4 & $4(44.4 \%)$ & $0(0 \%)$ & $0(0 \%)$ & & \\
\hline
\end{tabular}

Table 4: Assessment of effect of therapy on Objective parameters

\begin{tabular}{|c|c|c|c|c|c|c|}
\hline S. No. & $\begin{array}{c}\text { Assessment } \\
\text { Parameter }\end{array}$ & $\begin{array}{c}\text { Before T/t } \\
(\mathbf{m e a n} \pm \mathbf{S D})\end{array}$ & $\begin{array}{c}\text { After T/t } \\
(\mathbf{m e a n} \pm \mathbf{S D})\end{array}$ & $\begin{array}{c}\text { After Follow-up } \\
(\mathbf{m e a n} \pm \mathbf{S D})\end{array}$ & $\begin{array}{c}\text { t value } \\
\text { After FU }\end{array}$ & P value \\
\hline 1 & $\begin{array}{c}\text { Systolic Blood } \\
\text { Pressure (SBP) }\end{array}$ & $139.53 \pm 2.83$ & $131.14 \pm 3.05$ & $129.58 \pm 2.96$ & 12.69 & $0.0001, \mathrm{HS}$ \\
\hline 2 & $\begin{array}{c}\text { Diastolic Blood } \\
\text { Pressure (DBP) }\end{array}$ & $88.33 \pm 2.69$ & $80.17 \pm 2.75$ & $79.83 \pm 2.55$ & 10.89 & $0.0001, \mathrm{HS}$ \\
\hline
\end{tabular}

\section{Results}

Statistically significant results $(\mathrm{p}<0.05)$ were found which shows that Nitya Virechana with Trivrit Churna was statistically effective in reducing the intensity of symptoms of hypertension. The results obtained were highly significant $(\mathrm{p}<0.0001)$ in objective parameters which shows that Nitya Virechana with Trivrit Churna was highly effective in reducing the Systolic and Diastolic blood pressure even after follow up period. On summarizing the total effect of therapy, marked relief was found in 3 patients $(33.3 \%)$ and moderate relief was found in 6 patients $(66.7 \%)$ [Table $5]$.
Table 5: Assessment of total effect of therapy on the basis of percentage of relief in subjective parameters

Total effect of therapy Range $\%$ of relief

Controlled $100 \% \quad 0(0 \%)$

\begin{tabular}{l|l|l} 
Marked Relief & $\geq 75 \%$ & $3(33.3 \%)$
\end{tabular}

\begin{tabular}{l|l|l} 
Moderate Relief & $\geq 50-74 \%$ & $6(66.7 \%)$
\end{tabular}

\begin{tabular}{l|l|l} 
Mild Relief & $\geq 25-49 \%$ & $0(0 \%)$
\end{tabular}

\begin{tabular}{l|l|l} 
No Relief & $<25 \%$ & $0(0 \%)$
\end{tabular}




\section{Discussion}

Hypertension is one among the most alarming health disorder in today's time period. The lateral pressure exerted by blood on the lateral walls of blood vessels over and above the atmospheric pressure is said to be hypertension. In Ayurveda, there is no direct references regarding hypertension and as per Ayurvedic principles, in case of unknown disease, the physician should try to interpret the features of the disease through the involvement of Dosha, Dushya and its etiological factors involved in the pathogenesis of the disease and treat accordingly (18). Blood Pressure is the outcome of many physiological activities which is regulated by the Tridoshas viz Vata (Prana and Vyana), Pitta (Sadhaka), and Kapha (Avalambaka) Doshas, Dushyas like Rasa, Rakta and Meda, with the proper functioning of Mana and Oja which are situated in heart and helps in pumping of blood (19). On the basis of involvement of these factors, hypertension is said to be Vata Pradhana Tridoshaja Vyadhi.

Trivrit Churna predominantly has Madhura, Katu, Tikta, Kashaya Rasa, acts as Pittakaphahara and has Sukhavirechaka, Anulomana, Hridya, Raktashodhaka, Amapachaka, Vedanasthapana etc. properties and are indicated in Hridroga, Raktavikara, Jwara, Pleeha-yakruta Vyadhi etc (20). The chemical constituents of Trivrit comprises of Turpethinic acids, $\alpha$ and $\beta$-turpethin, lupeol, b-sitosterol, botulin etc (21). The laxative effect of Trivrit is mainly due to the presence of turpethin (22). This fundamental constituent is believed to work on mysentric plexus and increase peristaltic movements in the body, thus acts as a laxative. Operculina turpethum exhibit analgesic, carminative, anti-inflammatory, antioxidant, hepatoprotective, immunomodulatory and hydragogue activities (23). When administered as laxative helps in alleviating the symptoms of hypertension by initiating the excretion of sodium and reducing vascular resistance.

Mridu Sanshodhana has been mentioned as the line of treatment of Vata Vyadhi. Nitya Virechana is a type of Mridu Sanshodhana. The probable mode of action of Nitya Virechana with Trivrit Churna can be understood by the dominant pharmacodynamics which helps in removing obstruction (Margavarodha) and eliminates the excess morbid toxic materials (Kledamsha) through Adhobhaga by the predominance of Jala and Prithvi Mahabhutas. Thereby it helps in pacifying Kapha and Pitta Doshas which altogether has its effect on Rakta due to Ashraya-ashrayi Sambandha and regulates Vata Dosha by its Anulomana action and ultimately balances the Tridosha. Thus Nitya Virechana acts either by hyper osmotic action or by reducing fluid electrolyte retention in the blood helps in expulsion of morbid Doshas from the body in less quantity and thereby reduces the total volume of Rasa and Rakta and maintaining the electrolyte balance and ultimately decreased blood pressure. Hence, we can conclude that Nitya Virechana with Trivrit Churna acts by Pittakaphahara, Sukhavirechaka, Anulomana and Raktashodhaka properties, which helps in maintaining osmotic pressure, thereby regularize Tridosha and reduces hypertension.

\section{Conclusion}

Hypertension is a common disorder of present era. Essential Hypertension is a psychosomatic hemodynamic disorder which is well explained in modern medicine can be correlated with Vata Pradhana Tridoshaja Vyadhi in Ayurveda based on the similarities in etiological factors, clinical features, complications etc. Statistically significant reduction in clinical symptomatology of hypertension and significant improvement was found in Systolic and Diastolic blood pressure. From the outcomes, we can conclude that Nitya Virechana with Trivrit Churna is effective to reduce Systolic and Diastolic blood pressure in Stage 1 Essential Hypertension. In this study none of the patients had developed any adverse effects during the course of treatment. The sample size was small and the study duration was too short to draw exact conclusion, thus the study with large sample and optimum duration should provide more improvement.

\section{References}

1. Whelton PK, Carey RM, AronowWS, et al. ACC/ AHA/ AAPA/ ABC/ ACPM/ AGS/ APhA/ ASH/ ASPC/NMA/PCNA guideline for the prevention, detection, evaluation, and management of high blood pressure in adults. J AmColl Cardiol. 2017.

2. Chen S. Essential hypertension: perspectives and future directions. J Hypertens 2012;30(1):42-5.

3. WHO Report of Prevention and Control for Cardio Vascular Diseases, 2002, Available From http:// www.Sld.Cu/./ Pdf/./International Cardiovascular Disease Statistics. Page 2. dated 03/04/2017 time 17:10 IST

4. Gupta R. Trends in hypertension epidemiology in India, J of Human Hypertension 2004;18(2):73-78

5. Pierdomenico S.D. et Al. "Prognostic Value of Different Indices of Blood Pressure Variability in Hypertensive Patients." American Journal of Hypertension. 2009,22(8):842-7.

6. Nguyen Q, Dominguez J, Nguyen L, Gullapalli N. Hypertension management: an update. Am Health Drug Benefits 2010;3(1):47-56.

7. Forjaz CLM, et al. Genetic and environmental influences on blood pressure and physical activity: a study of nuclear families from Muzambinho, Brazil. Braz J Med Biol Res 2012;45(12):1269-75.

8. Tripathi KD. Essentials of Medical Pharmacology. 6th edition. New Delhi: Jaypee Brothers Medical Publishers (P) Ltd.; 2008. p. 546.

9. Ramesh bhayal. "Role of virechana karma and shaman chikitsa in the management of Uccharaktachapa (EHT)". IPGT \& R, Jamnagar; 2003.p11-12.

10. Sharma PV, editor. Charaka Samhita of Agnivesha, Sutrasthana, Vidhishonitiya Adhyaya. Chapter 24, Verse 5-10. $8^{\text {th }}$ ed. Varanasi, India; Chaukhamba Orientalia; 2007. p. 124. 
11. Sharma PV, editor. Charaka Samhita of Agnivesha, Sutrasthana, Vidhishonitiya Adhyaya. Chapter 24, Verse 11-16. 8th ed. Varanasi, India; Chaukhamba Orientalia; 2007. p. 124.

12. Sharma PV, editor. Charaka Samhita of Agnivesha, Sutrasthana, Vidhishonitiya Adhyaya. Chapter 24, Verse 25-27. $8^{\text {th }}$ ed. Varanasi, India; Chaukhamba Orientalia; 2007. p. 125.

13. Sharma PV, editor. Charaka Samhita of Agnivesha, Vimanasthana, Janapadodwansaniyavimana Adhyaya. Chapter 3, Verse 44. 8th ed. Varanasi, India; Chaukhamba Orientalia; 2007. p. 579.

14. Sharma PV, editor. Charaka Samhita of Agnivesha, Sutrasthana, Vidhishonitiya Adhyaya. Chapter 24, Verse 18. $8^{\text {th }}$ ed. Varanasi, India; Chaukhamba Orientalia; 2007. p. 124.

15. Tripathi B, editor. Ashtanga Hridayao of Acharya Vagbhata, Sutrasthana, Doshaadivigyana adhyaya. Chapter 11, Verse 26. Delhi, India; Chaukhamba Sanskrit Pratishthan; 2015. p. 165.

16. Tripathi B, editor. Ashtanga Hridaya of Acharya Vagbhata, Sutrasthana, Doshopkramaniya adhyaya. Chapter 13, Verse 1. Delhi, India; Chaukhamba Sanskrit Pratishthan; 2015. p. 185.

17. Sharma PV, editor. Charaka Samhita of Agnivesha, Sutrasthana, Yajyapurishiya Adhyaya. Chapter 25,
Verse 40. 8 $^{\text {th }}$ ed. Varanasi, India; Chaukhamba Orientalia; 2007. p. 168.

18. Sharma PV, editor. Charaka Samhita of Agnivesha, Sutrasthana, Trishothiya Adhyaya. Chapter 18, Verse 44. $8^{\text {th }}$ ed. Varanasi, India; Chaukhamba Orientalia; 2007. p. 281.

19. Sharma PV, editor. Charaka Samhita of Agnivesha, Chikitsasthana, Grahanidoshachikitsa adhyaya. Chapter 15, Verse 36. $8^{\text {th }}$ ed. Varanasi, India; Chaukhamba Orientalia; 2007. p. 366.

20. A.P. Deshpande, Subhash Ranade ed, Text book of DravaygunaVigyan (English), Part-2, A.R. Nandurkar, Proficient Publishing House 535,Shaniwar Peth, Pune; 2007. p.501.

21. Rastogi R, Mehrotra BN, Sinha S, Shrivastava M, Bhushan B. Compendium of Indian Medicinal Plants. Vol. 4. New Delhi, India; CDRI Lucknow \& National Institute of Science Communication; 2002. p. 513.

22. Nadkarni KM, Nadkarni AK, editor. Indian Materia Medica. Vol. 1. Popular Prakasan: Bombay;2007. p. 691-4.

23. Mhaskar KS, Blatter E, Caius JF, Kirtikar KR, Basu's BD. Illustrated Indian Medicinal Plants. Vol. 8. Delhi; Sri Satguru Publications; 2000. p. 2387-90. 